\title{
Marital Distress and Satisfaction During the COVID-19 Pandemic: A Systematic Review
}

\author{
Ignasia Epifani ${ }^{1}$, Shinta Wisyaningrum ${ }^{2}, \&$ Annastasia Ediati ${ }^{3 *}$ \\ ${ }^{1}$ Fakultas Psikologi, Universitas Diponegoro, Semarang, Indonesia \\ ${ }^{2}$ Fakultas Psikologi, Universitas Diponegoro, Semarang, Indonesia \\ ${ }^{3}$ Fakultas Psikologi, Universitas Diponegoro, Semarang, Indonesia \\ *Corresponding author.Email: ediati@lecturer.undip.ac.id
}

\begin{abstract}
COVID-19 pandemic brings tremendous impact on families, particularly on marital relationship. This paper reported findings on systematic review concerning the stressor and psychological problem encountered by married couples. We search in the Google Scholar database using the following keywords "marital satisfaction" and pandemic. We selected articles that met the inclusion criteria: original article, written in English, and fulltext available. From six articles that had been reviewed, we found out that either husband or wife are prone to domestic violence, working from home increase marital conflict because couples spend more time together every day and begin to know each other which often led to conflict. Fear of COVID-19 transmission influence sexual relationships and intimacy which subsequently reduce marital satisfaction. Marital distress and marital dissatisfaction were higher in couples who thoughts their spouses were irresponsive to their situation as marital conflict increased. Couples who believed that their spouses were responsive to their situation reported less marital distress and conflict and higher marital satisfaction. We conclude that during the COVID-19 pandemic, marriages are at risk and need psychoeducation supports designed for couples, particularly to improve their marital adjustment and communication, emotion regulation, managing conflict, problem solving, and building intimacy during crisis.
\end{abstract}

Keywords: COVID-19 Pandemic, Marital Distress, Marital Satisfaction.

\section{INTRODUCTION}

Around the world nowadays, countries are struggling to fight the spread of the disease (COVID-19) which later became a pandemic. The death rate due to the COVID-19 pandemic has reached 763,390 [1]. One of the steps used by the government to prevent the spread of this virus is by implementing a social isolation policy, where social isolation covers all aspects of life, from closing places of worship, recreational facilities, work, schools to shopping centres [2]. The lockdown has various sociological and psychological consequences resulting in disturbances in everyday life. It creates financial instability [3][4]. Due to the increasing number of people with COVID-19 and the death cases that follow, people experience psychological problems such as anxiety, depression and stress [2]. Drastic changes occur where the ability to connect socially and carry out daily activities is reduced or even absent [3]. Humans, as social beings, who have a need to relate to other people, become traumatized, the emergence of psychological problems such as anxiety, depression and stress when this social isolation is determined by the local government [4]. Changes in the situation at work due to the spread of the COVID-19 pandemic, which made most workers lose their jobs, reduced activity at work, and uncertainty in the economic sector made people become depressed. Relatives or acquaintances who become COVID-19 patients also contribute to the high level of anxiety experienced due to fear of contracting [5]. 
For couples living together, social isolation that removes other contacts facilitates an exclusively dyadic relationship, where critically, the rise in domestic violence since the implementation of movement restrictions suggest that this is not healthy for all romantic relationships [6]. Stay-at-home orders have forced many people in relationships to spend more time at home with their partner, either working or caring for children [7]. Maintaining a high-quality romantic relationship during times of heightened stress, such as in the case of the Covid-19 pandemic, is very challenging [8].

A person's subjective feelings about their marital relationship regarding roles, privacy preferences, prosperity, interpersonal relationships, and reciprocity, the existence of factors that give rise to conflict, motivation, understanding of the partner's mood and attributions can be termed marital satisfaction. A person is said to be satisfied with marriage if that person achieves one's goals in married life. Partner interaction and the level of consensus between one's anticipation of marriage and what benefits marriage provides about marital satisfaction. A healthy marriage is an honourable life experience. This can help a person feel supported, approved, wanted, and complete at a certain level where it is impossible to happen in other forms of human relationships [5]. From an international study involving 33 countries, it was known that India is a country with a higher level of marriage satisfaction than other countries [9]. In some cases, persons who experience dissatisfaction with their marriage, they reported stress which affects their mental health [10], as well as their physical health [11], and often impact on their parenting for children [12]. Previous studies revealed that couples who experience prolonged financial distress, lack of social relationships (loneliness), and have a high level of stress, were at a high risk of marriage dissatisfaction and marital conflict [13-15].

The way of thinking plays an important role in determining marital satisfaction. There are two types of ways of thinking: individuals who have a fixed or inflexible way of thinking and individuals who have flexible way of thinking [16]. A study was conducted to investigate stress due to the COVID-19 pandemic (social isolation, financial problems, tension, stress) associated with marriage satisfaction and conflict experienced by partners, through moderating variables in the form of the partner's perceived response, to what extent people believe that their partner understands, care, and understand [17]. The findings led us to wonder about what we have learned from studies assessing marital distress and marital satisfaction during the COVID-19 pandemic. This study aims to review studies reporting marital distress and marital satisfaction during the COVID-19 pandemic.

\section{METHOD}

We conducted systematic review study by following the guideline for conducting systematic review studies for psychological research [6] and PRISMA guideline for reporting systematic review [7]. We search in the Google Scholar database using the following keywords: "Marital satisfaction" AND pandemic OR "Marital Distress" AND pandemic. We used the following inclusion criteria: original articles, written in English, full text is available and accessible, and published in 2020. Articles reporting outside the scopes of couples, marital distress, marital satisfaction, COVID-19 pandemic were excluded.

We performed the literature search by putting all the inclusion criteria as filter, then screening on titles and abstracts of the articles. Subsequently, we read the fulltext and selected articles that unmet the inclusion criteria. From six articles that relevant for review, we extracted the data and presented in the form of matrix table that present the study focus, countries where the study was conducted, study design and instrument used, and results on marital distress and marital satisfaction. The article selection process can be seen in Figure 1 .

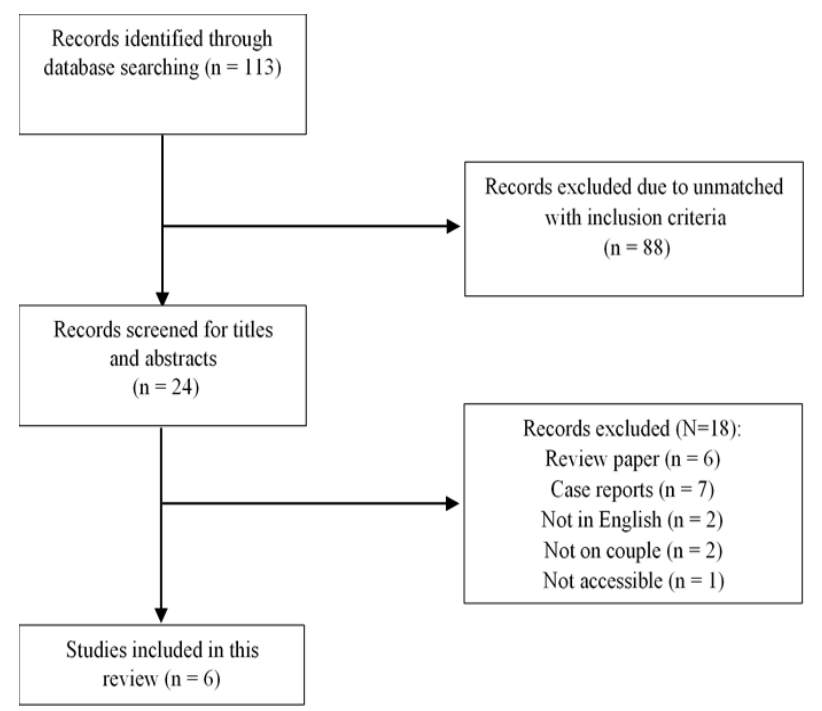

Figure 1 Flowchart of article selection process

\section{RESULT}

The literature search resulted in six studies reported distress on marriage and satisfaction with marriage by married couples during the COVID-19 pandemic, which began to hit the world in early 2020. Data were collected online using social media in 57 countries whereas 27 countries with all or most of the participants are married. The socio-economic status, flexibility of thinking to adapt to the current situation, loss of work may associate with violence by the partner. However, 
sexual behavior intensity could reduce stress levels in married women. Responsivity between husband and wife can make couples satisfied with their marriage and reduce stress during COVID-19 pandemic. Married couples had lower stress due to the COVID-19 pandemic than unmarried individuals. For detailed data extraction results can be seen in Table 1.

Table 1. Data extraction results

\begin{tabular}{|c|c|c|c|c|c|}
\hline \multirow[t]{2}{*}{ No } & \multirow{2}{*}{$\begin{array}{l}\text { Study focus / } \\
\text { Country [Ref] }\end{array}$} & \multirow[t]{2}{*}{ Participants } & \multirow[t]{2}{*}{ Instruments } & \multicolumn{2}{|c|}{ Results } \\
\hline & & & & Marital stress & Marital satisfaction \\
\hline 1 & $\begin{array}{l}\text { The effect of } \\
\text { socioeconomic } \\
\text { status and } \\
\text { perspectives on } \\
\text { marital satisfaction } \\
\text { during the period of } \\
\text { social isolation } \\
\text { during the pandemic } \\
\text { in Thrissur District, } \\
\text { Kerala, India [5] }\end{array}$ & $\begin{array}{l}172 \text { married } \\
\text { couples, aged } \\
25-60 \text { years. } \\
\text { ( } 90 \text { married } \\
\text { couples have } \\
\text { been married } \\
\text { for }<10 \text { years) }\end{array}$ & $\begin{array}{l}\text { The Couple } \\
\text { Satisfaction } \\
\text { Index (CSI-4) } \\
\text { Kuppuswamy } \\
\text { Socioeconomic } \\
\text { Scale } \\
\text { The Growth } \\
\text { Mindset Scale }\end{array}$ & $\begin{array}{l}\text { Individuals who have a } \\
\text { fixed perspective tend to } \\
\text { have low marital } \\
\text { satisfaction } \\
\text { Low socioeconomic status } \\
\text { tends to have low marriage } \\
\text { satisfaction }\end{array}$ & $\begin{array}{l}\text { Individuals who } \\
\text { have a dynamic } \\
\text { perspective tend to } \\
\text { have marital } \\
\text { satisfaction. } \\
\text { High socioeconomic } \\
\text { status tends to have } \\
\text { high marital } \\
\text { satisfaction }\end{array}$ \\
\hline 2. & $\begin{array}{l}\text { The role of social } \\
\text { pressure on violence } \\
\text { by partners, socio- } \\
\text { demographic factors } \\
\text { and economic } \\
\text { difficulties that can } \\
\text { trigger violence } \\
\text { against partners } \\
\text { during the } \\
\text { imposition of social } \\
\text { isolation in Nigeria } \\
\text { [8] }\end{array}$ & $\begin{array}{l}356 \text { married } \\
\text { couples, } 215 \\
\text { women and } \\
141 \text { men; aged } \\
18-68 \text { years. } \\
176 \text { couples } \\
\text { live with the } \\
\text { nuclear } \\
\text { family; } 180 \\
\text { couples live } \\
\text { with the } \\
\text { extended } \\
\text { family }\end{array}$ & $\begin{array}{l}\text { The Composite } \\
\text { Abuse Scale } \\
\text { (Revised)- } \\
\text { Short Form } \\
\left(\text { CAS }{ }_{R}-S R\right)\end{array}$ & $\begin{array}{l}\text { Violence committed by a } \\
\text { partner regardless of } \\
\text { gender, male or female can } \\
\text { become victims of violence } \\
\text { committed by a partner. } \\
\text { Social status is significantly } \\
\text { associated with violence } \\
\text { committed by partners, the } \\
\text { lower the income level, the } \\
\text { more violent behaviour } \\
\text { towards partners occurs } \\
\text { during the COVID-19 } \\
\text { pandemic. }\end{array}$ & $\begin{array}{l}\text { Work status that has } \\
\text { financial security, } \\
\text { low violent } \\
\text { behaviuor towards } \\
\text { partners. }\end{array}$ \\
\hline 3 & $\begin{array}{l}\text { Relationship } \\
\text { between quality of } \\
\text { life of married } \\
\text { Iranian women on } \\
\text { levels of anxiety } \\
\text { and depression, } \\
\text { anxiety due to } \\
\text { COVID-19 } \\
\text { pandemic, sexual } \\
\text { function and marital } \\
\text { satisfaction. [9] }\end{array}$ & $\begin{array}{l}296 \text { married } \\
\text { women, aged } \\
18-45 \text { years. } \\
\text { Additional } \\
\text { criteria: no } \\
\text { history of } \\
\text { chronic } \\
\text { diseases or } \\
\text { else causing } \\
\text { sexual } \\
\text { problems, not } \\
\text { taking drugs } \\
\text { affecting } \\
\text { sexual } \\
\text { response, not } \\
\text { addicted to } \\
\text { nicotine and } \\
\text { alcohol, have } \\
\text { had sexual } \\
\text { intercourse in } \\
\text { the last month }\end{array}$ & $\begin{array}{l}\text { Short Form } \\
\text { Health Survey } \\
\text { (SF-12) } \\
\text { The Female } \\
\text { Sexual } \\
\text { Function Index } \\
\text { (FSFI) } \\
\text { Hospital } \\
\text { Anxiety and } \\
\text { Depression } \\
\text { Scale } \\
\text { Marital } \\
\text { Satisfaction } \\
\text { Scale (MSS) } \\
\text { General Health } \\
\text { Questionnaire } \\
\text { (GHQ) } \\
\text { Corona } \\
\text { Anxiety Scale }\end{array}$ & $\begin{array}{l}\text { Anxiety, depression and } \\
\text { anxiety related to the } \\
\text { COVID-19 pandemic have } \\
\text { a negative impact on health. } \\
\text { On the other hand, health } \\
\text { does not directly affect } \\
\text { sexual behaviour. }\end{array}$ & $\begin{array}{l}\text { Married women with } \\
\text { a high level of } \\
\text { sexual activity tend } \\
\text { to have satisfaction } \\
\text { with their marriage, } \\
\text { which then has an } \\
\text { effect on the married } \\
\text { woman's quality of } \\
\text { life for the better. }\end{array}$ \\
\hline 4 & $\begin{array}{l}\text { The causes of stress } \\
\text { associated with the }\end{array}$ & $\begin{array}{l}3593 \text { married } \\
\text { couples }(82 \%\end{array}$ & $\begin{array}{l}\text { UCLA } \\
\text { Loneliness }\end{array}$ & $\begin{array}{l}\text { Distress during the } \\
\text { COVID-19 pandemic was }\end{array}$ & $\begin{array}{l}\text { Individuals who feel } \\
\text { that their partner is }\end{array}$ \\
\hline
\end{tabular}




\begin{tabular}{|c|c|c|c|c|c|}
\hline & $\begin{array}{l}\text { COVID-19 } \\
\text { pandemic due to the } \\
\text { determination of } \\
\text { social isolation, } \\
\text { financial pressure } \\
\text { and stress } \\
\text { associated with the } \\
\text { quality of marital } \\
\text { relationships in } 57 \\
\text { countries [10] }\end{array}$ & $\begin{array}{l}\text { heterosexual } \\
\text { couples, } \\
13.2 \% \\
\text { bisexual } \\
\text { couples, } 4.3 \% \\
\text { gay / lesbian } \\
\text { couples). Age } \\
\text { in early } 30 \\
\text { years. } \\
\text { Living } \\
\text { together } \\
83.7 \% \text {, living } \\
\text { separately } \\
9.4 \% \text { and } \\
\text { sometimes } \\
\text { living together } \\
6.9 \%\end{array}$ & $\begin{array}{l}\text { Scale } \\
\text { Single item to } \\
\text { assess financial } \\
\text { strain } \\
\text { Perceived } \\
\text { Partner } \\
\text { Insensitivity } \\
\text { Scale } \\
\text { Perceived } \\
\text { Relations } \\
\text { Quality Scale } \\
\text { Marital conflict }\end{array}$ & $\begin{array}{l}\text { caused by the social } \\
\text { isolation and financial } \\
\text { problems leading to marital } \\
\text { dissatisfaction. } \\
\text { Individuals who feel their } \\
\text { partners were irresponsive } \\
\text { to the stress due to the } \\
\text { COVID-19 pandemic, } \\
\text { couples with social } \\
\text { isolation and financial } \\
\text { difficulties, reported } \\
\text { dissatisfied and tend to } \\
\text { have more conflicts with } \\
\text { their partners. }\end{array}$ & $\begin{array}{l}\text { responsive to the } \\
\text { stress they } \\
\text { experienced, tend to } \\
\text { be satisfied with } \\
\text { their marriage and } \\
\text { do not experience } \\
\text { conflict with their } \\
\text { partners due to the } \\
\text { COVID-19 } \\
\text { pandemic, which } \\
\text { affects social } \\
\text { isolation and } \\
\text { financial difficulties }\end{array}$ \\
\hline 5 & $\begin{array}{l}\text { Psychosocial factors } \\
\text { influence violence } \\
\text { perpetrated by } \\
\text { partners during the } \\
\text { COVID-19 } \\
\text { pandemic taking } \\
\text { place in Nigeria, } \\
\text { [11] }\end{array}$ & $\begin{array}{l}356 \text { married } \\
\text { couples (141 } \\
\text { males, } 215 \\
\text { females). }\end{array}$ & $\begin{array}{l}\text { Big Five } \\
\text { Inventory Scale } \\
\text { (BFI-10) } \\
\text { Traits } \\
\text { Emotional } \\
\text { Intelligence } \\
\text { Questionnaire } \\
\text { (TEIQue-SF) } \\
\text { The Composite } \\
\text { Abuse Scale } \\
\text { (Revised)- } \\
\text { Short Form } \\
\text { (CAS }-S F)\end{array}$ & $\begin{array}{l}\text { Personality dimension is } \\
\text { significantly related to } \\
\text { violence perpetrated by a } \\
\text { partner. Personality } \\
\text { characteristics and } \\
\text { emotional immaturity } \\
\text { associated with the violent } \\
\text { behaviour towards partner. } \\
\text { There are significant } \\
\text { correlations between living } \\
\text { conditions and job status, } \\
\text { but violence by partner is } \\
\text { not associated to gender, } \\
\text { religion and type of family. }\end{array}$ & \\
\hline 6 & $\begin{array}{l}\text { The family size, } \\
\text { age, sex, marital } \\
\text { status, and number } \\
\text { of children, the } \\
\text { existence of a } \\
\text { culture of } \\
\text { individualism and } \\
\text { Collectivism are } \\
\text { associated with the } \\
\text { stress level caused } \\
\text { by social isolation } \\
\text { during the COVID- } \\
19 \text { pandemic in } 26 \\
\text { countries [12] }\end{array}$ & $\begin{array}{l}53,524 \\
\text { participants. } \\
18,288 \\
(34.2 \%) \text { men; } \\
34,475 \\
(64.6 \%) \\
\text { women. Aged } \\
18-110 \text { years. } \\
26,429 \\
\text { married } \\
\text { couples } \\
(49.4 \%), \\
\text { divorced } \\
(6.8 \%), \\
45.8 \% \text { were } \\
\text { isolated. } \\
48.7 \% \text { felt life } \\
\text { had changed a } \\
\text { little; } 5.4 \% \\
\text { felt life was as } \\
\text { usual. }\end{array}$ & $\begin{array}{l}\text { Perceived } \\
\text { Stress Scale } \\
(P S S)\end{array}$ & & $\begin{array}{l}\text { Married individuals } \\
\text { reported lower stress } \\
\text { than singles. In line } \\
\text { with previous } \\
\text { findings that } \\
\text { highlight the benefits } \\
\text { of intimate } \\
\text { relationships from } \\
\text { married couples, } \\
\text { intimate interactions } \\
\text { between two people } \\
\text { can make up for the } \\
\text { deficiencies that } \\
\text { exist in a } \\
\text { relationship. This } \\
\text { protective factor } \\
\text { plays a very } \\
\text { important role, } \\
\text { especially in difficult } \\
\text { situation where } \\
\text { many married } \\
\text { couples having } \\
\text { financial difficulties. }\end{array}$ \\
\hline
\end{tabular}




\subsection{Discussion}

Research on socioeconomic status and the perspective that a person has in assessing the quality of their marriage shows that middle to lower socioeconomic status tends to be low in marriage satisfaction, while individuals with middle and upper socioeconomic status tend to judge that they are satisfied with their marriage. Besides, a person who has a character with a relatively fixed ways of thinking tends to have low marriage satisfaction. During this period of social isolation in the COVID19 pandemic, those who have this way of thinking have become more observant of the lack of partners due to more time at home. Seeing that the conflict that occurred with the partner was a failure in the relationship. Those who have this trait see marriage to share the perfect relationship, if it turns out that the existing relationship is messy then they think that this is fate, so they don't feel the need to try to make this messy relationship better. In addition, those who have a sedentary perspective tend to find it difficult to adapt, so that the lack of partners who were not visible before the social isolation period often irritates and creates conflict. Marriage satisfaction is also seen from the socioeconomic status of the individual. Individuals with low socioeconomic status tend to be dissatisfied with their marriages while individuals with middle and upper socioeconomic status tend to be satisfied with their marriages. Found that economic hardship can have an impact on the emergence of psychological symptoms such as stress, anger, traumatic, which in turn can reduce satisfaction in marriage [13]. The stress model in the family developed by Conger et al, states that economic pressure makes more bitterness and less comfortable in interacting between partners. With the implementation of social isolation during the COVID-19 pandemic, many people have lost their jobs and they tend to project their problems caused by economic hardship into their interpersonal relationships. This may be the basis for the low satisfaction of marriage with economic status [5].

Personality type also influence the individual's stress level during the COVID-19 pandemic which may lead to violent behaviour towards a spouse. Based on five types of personality traits (extraversion, consciousness, neuroticism, agreeableness, and openness to experience), neuroticism personality predicts violent behaviour towards partners. Furthermore, it was found that personality traits did not have a significant relationship with cases of violence against partners. Emotional maturity levels can go along with personality traits or walk on their own. This means that the two do not influence each other. There is still limited research on the effect of emotional intelligence on violent behaviour towards partners, especially those related to the COVID-19 pandemic, so this study was conducted and found that low emotional intelligence triggers violence against partners. Individuals who commit violence against their partners lack of skills in managing emotions, especially when stress occurs due to a pandemic [11].

Socioeconomic status has a significant effect on violent behaviour towards partners, during the social isolation period in the COVID-19 pandemic. Spouse's income status can be a protective factor to reduce this behaviour [8]. Demographic factors such as gender, religion, age, family type and quality of life did not have a significant relationship with cases of violence against partners. Only the type of work has a significant relationship. Those who work in the government tend not to show violent behaviour towards their spouses, the types of work that have a significant relationship are entrepreneurial jobs, craftsmen, private employees, where they are directly affected by the COVID-19 pandemic. cases of violent behaviour against partners. There is no significant difference between gender and violent behaviour towards partners because both men and women can be the perpetrators or victims of this violence [8].

Marital satisfaction is defined as subjective feeling that a person has for certain elements in his marriage. It includes role functions, personal preferences, welfare, interpersonal relationships and interpersonal relationships, factors of disputes that occur in marriage, motivation, understanding of the partner's mood and attributions. It can be said that someone is satisfied with their marriage when that he/she can achieve their marriage goals, has successfully build interactions with his/her partner, understands each other about the meaning of marriage and benefits from marriage, makes the them feel satisfied with their marriage [5]. Satisfaction towards marriage can be a tremendous resource when faced with stress or problems due to pandemic. A warm and intimate relationship with a partner is one of the strongest predictors of health and well-being [14][15][16]. 
Research on marital satisfaction during the COVID-19 pandemic found that more stressors related to the COVID-19 pandemic, resulting in feelings of dissatisfaction with marriage and reduced commitment between partners which resulted in frequent conflicts with partners. Couples with the determination of the status of social isolation and economic hardship, this has increased dissatisfaction with marriage and low commitment, which has resulted in more frequent conflicts. Furthermore, the couple's response to this negative relationship is also seen due to stress caused by the COVID-19 pandemic, such as social isolation, economic hardship and other pressures. Overall, it is reported that there is an effect of the partner's response to negative conditions as a result of the emergence of stress due to the pandemic which creates economic hardship and social isolation. Individuals who feel their partner's response is low, in the face of this negative condition, tend to have low marital satisfaction which is also due to more frequent conflicts. On the other hand, individuals who feel that their partner is more responsive to these negative conditions, feel satisfaction in their marriage and tend not to experience ongoing conflicts. However, the response of the couple due to the effect of social isolation, financial difficulties on the commitment of the partner is not related [10].

Women are more at risk of experiencing it, marital status has a lower stress level than single due to the COVID-19 pandemic. This is in line with previous study that highlighted the benefits of intimacy in partners [17], where the intimate interaction of two people in a relationship is able to cover up the shortcomings of their partner. It can be concluded that intimate interaction brings more benefits than harm [18]. This protective factor plays an important role, especially in times of difficulty, such as times of financial difficulty [19], with higher levels of education, stress levels are lower, and children who live with other people have high stress levels due to the pandemic [12]. Study revealed that quality of life in married women is associated with stress due to the COVID-19 pandemic. Moreover, pandemic-related anxiety is directly related to the quality of life of married women. Altogether, pandemic-related anxiety, depression and other anxiety related to women's general health. General health is not related to sexual behaviour that affects the quality of life of a married woman. Married women with good sexual function show satisfaction in marriage which is then associated with a good quality of life [9].

\subsection{Conclusion}

COVID-19 pandemic impacts many aspects of life, including marital relationship. Financial insecurity, job insecurity, and social isolation emerge as potential threats to the family due to reduced or loss of income that led to distress and aggression towards partner. Couples with inflexibility tend to encounter marital adjustment problems and perceived marital conflicts as failure to maintain relationship. Distress during the pandemic were reported among married women due to fear of their health. Distress on married women impacts their sexual relationship and subsequently influence their marital satisfaction and quality of life. Distress couple tend to have low commitment, low marital satisfaction, and frequent conflicts with their partner. Couple who are responsive to their partner tend to have less conflict and higher marital satisfaction toward their partner. Based on these findings, we conclude that during the COVID-19 pandemic, marriages are at high risk and couples need supports in maintaining their marital relationships. A psychoeducation intervention that specifically designed for couples to survive their marriages are strongly needed, particularly to improve their marital adjustment and communication, emotion regulation, managing conflict, problem solving, and building intimacy during crisis.

\section{AUTHORS' CONTRIBUTIONS}

IE and AE designed the study, drafting and finalizing the manuscript. IE and SW involved in data search, data analysis, drafting and finalizing the paper.

\section{ACKNOWLEDGMENTS}

We thanked Fakultas Psikologi Universitas Diponegoro for supporting the study. We declared no conflict of interests.

\section{REFERENCES}

[1] Worldometer. Countries in the World by Population. 2020 [Online]. Available: https://www.worldometer.info/worldpopulation/population-by-country/

[2] WHO. Coronavirus Disease (COVID19) situation Report. 2020

[3] M. D. S. James K. Jackson, Martin A. Weiss, Andres B. Schwarzenberg, Rebecca M. 
Nelson, Karen M. Sutter, "Global Economic Effects of COVID 19," 2021, Congressional Research Service Report [Online]. Available: https://fas.org/sgp/crs/row/R46270.pdf.

[4] A. Gangopadhyaya, A. B. Garrett, Unemployment, Health Insurance, and the COVID-19 Recession, SSRN Electronic Journal, 2020. pp. 1-8 DOI: https://doi.org/10.2139/ssrn.3568489

[5] J. Kevin, N. Risla. Influence of socioeconomic status and mindset on individual's marital satisfaction during the national lockdown, Int J Indian Psychol. 8(2) (2020) DOI: $10.25215 / 0802.059$

[6] M. A. dos Santos. Carvalho, L.de Francisco, G. Pianowski. Guidelines for conducting and publishing systematic reviews in psychology. Theory Methods Psychol. 36 (2019) DOI:10.1590/1982$0275201936 \mathrm{e} 180144$.

[7] D. Moher, A. Liberati, J. Tetzlaff, D. G. Altman. Preferred reporting items for systematic reviews and meta-analyses: The PRISMA statement. PLoS Med. 6(7). 2009 DOI: 10.1371/journal.pmed.1000097

[8] A. S. Okhakhume, R. Oguntayo, O. T. Aroniyiaso. Influence of socio-economic status and marital satisfaction on domestic violence among couples living in Nigeria," Int. J. Appl. Psychol. 6(6) (2016) 179-184 DOI: 10.5923/j.ijap.20160606.03

[9] D. Zahra, S. J. Sadatmahalleh, Y. Samaneh, B. K. Mahnaz, K. Anoshiravan. Influential factors on quality of life in married Iranian women during the Covid-19 pandemic in 2020: A path analysis. Research Square. (2020) 1-16. DOI: 10.21203/rs.3.rs-27439/v1

[10] R. N. Balzarini et al., Love in the time of COVID: Perceived partner responsiveness buffers people from lower relationship quality associated with COVID-related stressors. Manuscript submitted for publication. DOI: 10.31234/osf.io/e3fh4

[11] R. Oguntayo, A.O. Popoola, R. Opayemi, F. Omolara. Spousal violence in the era of COVID-19 lockdown: The implication of socioeconomic distress and contextual factors. Ilorin J Econ Policy, 7(3) (2020) 5160

[12] M. Kowal et al., "Who is the most stressed during the COVID-19 pandemic? Data from
26 countries and areas. Appl. Psychol.: Health Well-Being, (2020) 1-21 DOI: 10.1111/aphw.12234

[13] R.D. Conger, M.A. Rueter, G.H. Elder. Couple resilience to economic pressure, J Pers Soc Psychol 76(1) (1999) 54-71 DOI: 10.1037/0022-3514.76.1.54

[14] J. Holt-Lunstad, T. B. Smith, J. B. Layton. Social relationships and mortality risk: A meta-analytic review, PLoS Med. 7(7) (2010) DOI: 10.1371/journal.pmed.1000316

[15] P.R. Pietromonaco, L.A. Beck. Adult attachment and physical health, Curr Opin Psychol. 25 (2019) 115-120, 10.1016/j.copsyc.2018.04.004

[16] P.R. Pietromonaco, N.L. Collins. Interpersonal mechanisms linking close relationships to health, Am Psychol 72(6) (2017) 531- 542 DOI: 10.1037/amp0000129

[17] S. R. Braithwaite, R. Delevi, F. D. Fincham, Romantic relationships and the physical and mental health of college students. Pers. Relatsh. 17(1) (2010) 1-12 DOI: 10.1111/j.1475- 6811.2010.01248.x.

[18] C. A. Merz, N. Meuwly, A. K. Randall, G. Bodenmann. Engaging in dyadic coping: Buffering the impact of everyday stress on prospective relationship satisfaction. Fam Sci. 5(1) (2014) 30- 37 DOI: $10.1080 / 19424620.2014 .927385$

[19] H. M. Helms, A. J. Supple, J. Su, Y. Rodriguez, A. M. Cavanaugh, N. D. Hengstebeck. Economic pressure, cultural adaptation stress, and marital quality among mexican-origin couples. J Fam Psychol. 28(1) (2014) 77-87 DOI:10.1037/a0035738. 